\title{
Power Generation By Utilizing The Compound Gases With Spilled Oil At Using Power Chimney Techniques
}

\author{
Dr. Rafid M. Hannun \\ Assist. Dean of College of Engineering, Thi-Qar University
}

\section{$\underline{\text { Abstract }}$}

\section{The power chimney tower is}

one of modern promised energy which may be developed by low losses, simple and has high facilities.

In this paper, many parameters were studied exactly which influenced the prediction of system operation and fundamentally depend on the combustion of gases compound the spilled oil. Velocity distribution is the important parameter which gives the first prediction to put the position of erection of power turbine, made or not. The numerical analysis was presented by using GAMBIT and FLUENT 6.3 to predict that high velocity at the expansion of chimney near the centre of burned gases cover collector. This position is very suitable for promoting and building the power turbine since the velocity was more than (33 $\mathrm{m} / \mathrm{s}$ ) when the compounded gases is combusted (that there components are the methane gas with other friendly gases and waste. It is easy to erect steam or gaseous boiler in contact with furnace for utilize the heat generated in electrical power generation. So, the other factors, temperature and pressure were studied to coincide with previous papers in this field. 


\section{خلاصة البحث}

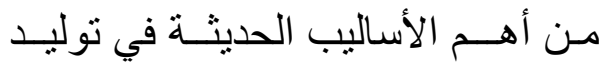
الطاقــة هي مدخنة القدرة لسهولتهـا وقلة مفاقيدها وتعقيداتها. في هذا البحث، تمت دراسة العو امل المهمة التي لها تأثير أ مباثرأ على عمل منظومة القدرة والتي تعمل بثكل اساسى اعتمادآ على حرق الغازات المصاحبة للنفط المستخرج. واهم تلك العوامل هو الفو الفي توزيع السرعة الذي ينبئ أو لا بموقع تتصيب ترباين القدرة ومكان تتصيبه. تم تقديم تحليل عددي وباستخدام برنامج الكامبتو الفلونت للتنبؤ بمكان أعلى سرعة قرب توسع الدخنة في مركز

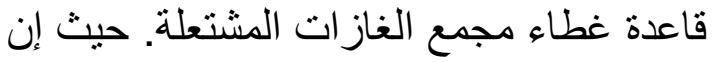
هذا الدكان هو الأكثر ملائمة لبناء ترباين القدرة العثاء ودعمه لكون سرع الهو اء قد وصلت إلى مديات تجاوزت (33 م/ثا) عند حرق الغاز ات المصاحبة لللنفط والتي تكون على الاغلب مكونة من غاز الميثان و غاز ات وشو ائب مصاحبة. ايضأ يمكن الاستفادة من حرارة الفرن بنصب مرجل بخاري او غازي لتوليد الكهرباء. كذلك تمت دراسة العوامل الأخرى المؤثرة على كفاءة المنظومة الكة مثل درجة الحرارة وفرق الضغط وتبين إنها متو افقة لما تم دراسته سابقأ من قبل الباحثين في التي التها

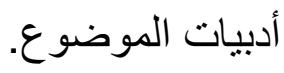

\section{1- Introduction:}

$\mathrm{P}_{\text {ower chimney technology is }}$ a promising large scale of power generation. This technology was first described by Gǜnter in 1931 and tested with the $50 \mathrm{kw}$ Manzanares prototype plant since 1980 [1]. There are four components for the combination of this prototype: combustion chamber, chimney, turbine connected with electrical generator.

The installation of power chimney at locations near the oil spilling stations for utilizing of compound gases which burned in this suggested power plant.

The compound gases pass through burner vent which circumstances with air vent to create high mixing rate to combust inside the cub of combustion chamber. The air near the ground absorbs the heat to decrease its density. The hot air particles move up to hit the cub ceiling continuously and go to chimney vent. This series 
heating generates continuous

movement of air, then, generates electrical energy by installing turbine connected to electrical generator.

The height of chimney causes high pressure difference between the upper and lower points. This pushes increasingly the movement of air particles between the lower points of chimney to up. In addition, the power may be generated by connecting gas or steam turbine to use the resulting hot gases before chimney inlet vent.

Gaseous fuels are usually characterized by clean combustion, with low rates ofsoot and nitric oxides. The main problem is achieving the optimal level ofmixing in the combustion zone. A mixing rate that is too high produces narrowstability limits, but a mixing rate that is too low may make the system prone tocombustion-induced pressure oscillations. Many different methods have been used to inject gas into conventional combustion chambers, including plain orifices, slot, swirlers, and venture nozzles [2].

Backstrom and Fluri [3] developed two analyses for finding the optimal ratio of turbine pressure drop to available pressure drop in a chimney power plant to be $2 / 3$ for maximum fluid power and using the power law model for this prediction. Haafet al. [4] , Haaf [5] and Schlaich [6] described the operation and presented results for a prototype solar chimney power plant built in Manzanares, Spain in 1982.

Pretorius and Kröger [7] evaluated the influence of a recently developed convective heat transfer equation, more accurate turbine inlet loss coefficient, the performance of a large scale chimney power plant. This simulation of study concluded that the new heat transfer equation reduce the annual plant power output by $11.7 \%$, but, the more realistic turbine inlet loss coefficient only accounts for a $0.66^{\circ}$ rise in annual power production. 
Ninic and Nizetic [8] developed and use the availability of warm, humid air via the formation of up draft "gravitational vortex column" situated over turbine with numerical solution for chimney power plant.

Sislian et.al. (1988) [9] measured experimentally many mechanical parameters in combustor and concluded that turbulence in the jet diffusion flamewas appreciably more anisotropic than in the corresponding cold jet in all regions ofthe flow. Love et.al. (2009) [10] developed an experimental method for the rapid characterization of combustion properties, and measured the amounts of NOx and combustion products,Azazi (2001)[11] presented a study to Hartha power plant furnace in Iraq, useda two dimensional aerodynamics and thermal aspects by using FORTRAN computer program. He concluded that $1500 \quad{ }^{\circ} \mathrm{C}$ inside temperature of furnace and the tangential velocity played a great role for keeping the stability of the fire ball. Alhabbubi (2002) presented a prediction of temperature distribution and heat flux along the walls of Al-Mussaib thermal power plant furnace in Iraq by usingzonal method to analyze the radiative heat transfer. He found the temperature range from $1450 \mathrm{~K}$ to $2100 \mathrm{~K}$.Sobolev et.al. (2008)[13] presented a numerical calculation results of methane turbulent diffusion jet flames of rectilinear-swirl burner in the furnace of high capacity boiler by using CFD AnsysCFX10.0 program. Hannun (2009) [14] studied the combustion of liquid and gaseous fuel in Nassiriya power plant furnace, analyzed numerically the mechanical properties by using FLUENT code,Hannun et.al. (2011) [15] presented a prediction for mechanical parameters influenced the operation of solar power chimney at Nassiriya city. 


\section{2-Numerical model}

\section{$\underline{\text { 2-1 Physical model }}$}

In this study, practical prototype is logically depended on as shown in Fig. 1, and is selected as a physical model for simulation. The chimney height is $50 \mathrm{~m}$ and radius 1 $\mathrm{m}$, the frustum (cup) of $15 \mathrm{~m}$ radius at the base and $10 \mathrm{~m}$ height. There are eight burners arranged around the chimney centre to ensure continuous, efficient flame stability. Each burner consists of central vent $(0.5 \mathrm{~m}$ radius $)$ for entering gaseous fuel, the outer vent ( $1 \mathrm{~m}$ radius) for flowing of air. There is a circular air vent at the base of chamber with height of $0.5 \mathrm{mto}$ allow the access air to enter to assist in rotating the turbine.

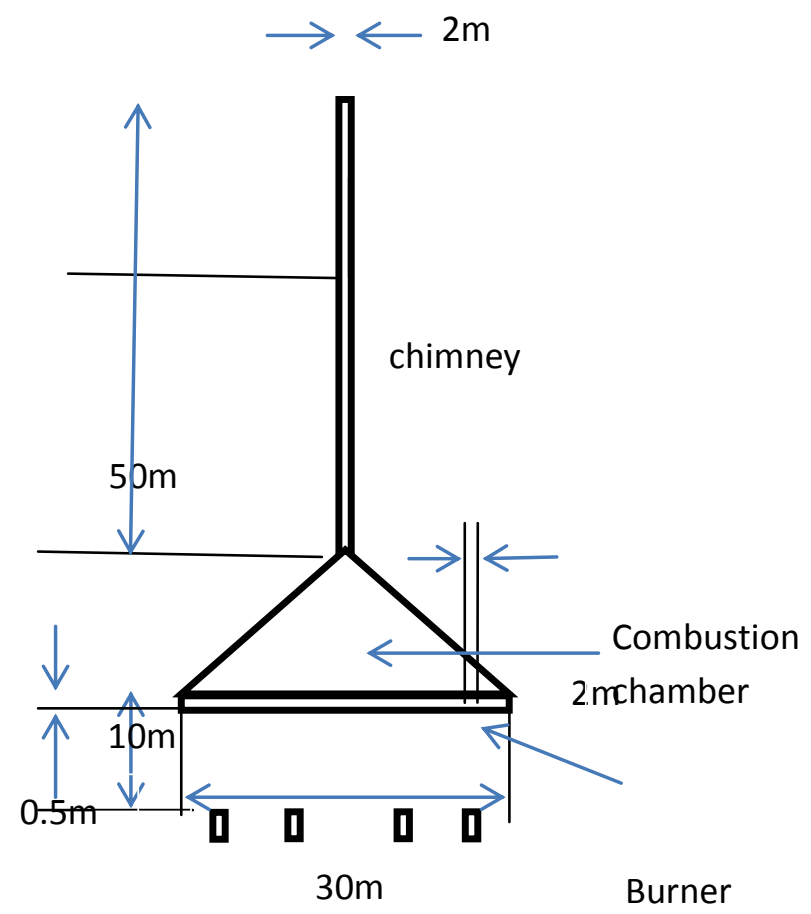

Fig.(1) Physical Prototype 


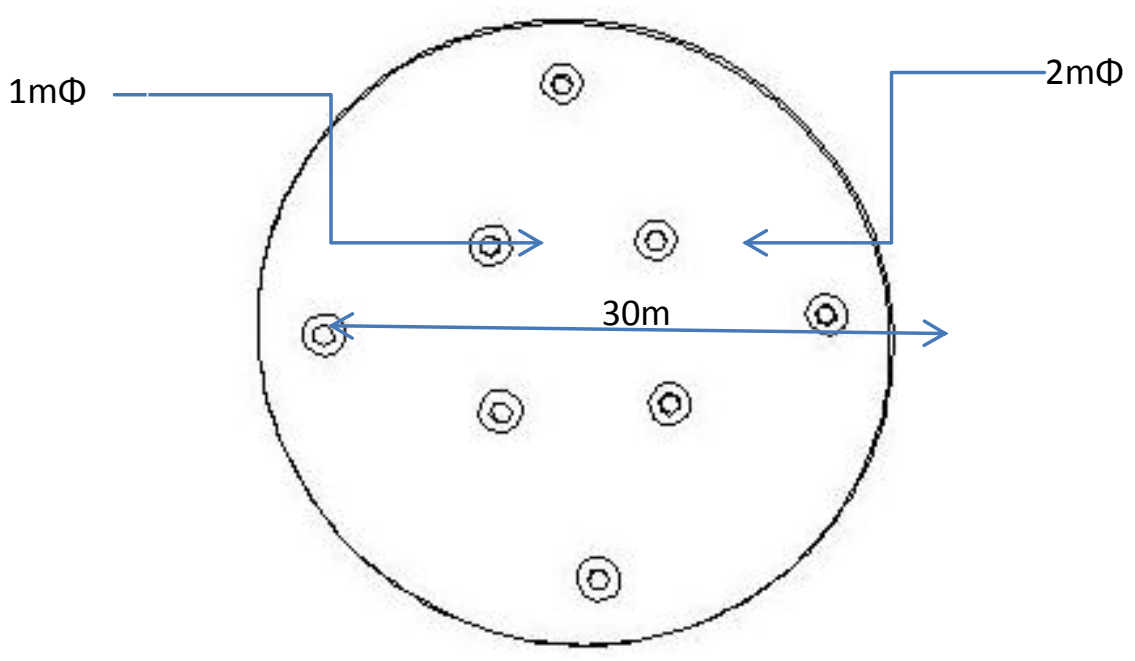

Fig.(2) Base And Burners Of Prototype

\section{$\underline{\text { 2-2 Mathematical Model }}$}

\section{There are many prototypes}

in the world that have large different heights of chimney up to $500 \mathrm{~m}$, with different radii. The designs of combustion chamber have many shapes and different dimensions. The design mentioned in previous paragraph (2-1) is corresponded as model to be analyzed. The buoyancy induced as . natural convection is measured by Rayleigh number $(\mathrm{Ra})$ :

$\mathrm{R}_{\mathrm{a}}=\mathrm{g} \beta\left(\mathrm{T}_{\mathrm{h}}-\mathrm{T}_{\mathrm{C}}\right) \mathrm{L}^{3} / \mathrm{av}$

Where $T_{h}, T_{C}$ is the maximum and minimum temperature of the system respectively. The $\mathrm{Ra}$ in this system analysis shows that $\mathrm{Ra}>10^{\wedge} 10$, therefore the flow is turbulent. The continuity, Navier - Stokes, energy equations and $\mathrm{k}-\varepsilon$ equation are shown below[9]: 


$$
\begin{aligned}
& \frac{\partial \rho}{\partial t}+\frac{\partial(\rho u)}{\partial x}+\frac{\partial(\rho v)}{\partial y}=0 \\
& (1) \\
& \frac{\partial(\rho u)}{\partial t}+\frac{\partial(\rho u u)}{\partial x}+\frac{\partial(\rho v u)}{\partial y}=\rho g \beta\left(T-T_{\infty}\right)+\mu\left(\frac{\partial^{2} u}{\partial x^{2}}+\frac{\partial^{2} u}{\partial y^{2}}\right)(2) \\
& \frac{\partial(\rho v)}{\partial t}+\frac{\partial(\rho u v)}{\partial x}+\frac{\partial(\rho v v)}{\partial y}=-\frac{\partial p}{\partial y}+\mu\left(\frac{\partial^{2} v}{\partial x^{2}}+\frac{\partial^{2} v}{\partial y^{2}}\right)(3) \\
& \frac{\partial(\rho c T)}{\partial t}+\frac{\partial(\rho c u T)}{\partial x}+\frac{\partial(\rho c v T)}{\partial y}=\lambda\left(\frac{\partial^{2} T}{\partial x^{2}}+\frac{\partial^{2} T}{\partial y^{2}}\right)(4) \\
& \frac{\partial}{\partial t}(\rho K)+\frac{\partial}{\partial x_{i}}\left(\rho K u_{i}\right)=\frac{\partial}{\partial x_{j}}\left(\left(\mu+\frac{\mu_{t}}{\sigma_{K}}\right) \frac{\partial K}{\partial x_{j}}\right)+G_{K}+G_{b}-\rho \varepsilon+S_{K} \\
& \frac{\partial}{\partial t}(\rho \varepsilon)+\frac{\partial}{\partial x_{j}}\left(\rho \varepsilon u_{i}\right)=\frac{\partial}{\partial x_{j}}\left(\left(\mu+\frac{\mu_{t}}{\sigma_{K}}\right) \frac{\partial \varepsilon}{\partial x_{j}}\right)+C_{i \varepsilon}\left(G_{K}+C_{3 \varepsilon} G_{b}\right)-C_{2 \varepsilon} \rho \frac{\varepsilon^{2}}{K}+S_{\varepsilon}
\end{aligned}
$$

\section{2-3 Boundary Conditions:}

1. For chimney

$\frac{\partial T}{\partial X}=0, u=0, v=0$

For the base inside the combustion chamber

$$
\frac{\partial T}{\partial y}=0, u_{d}=0, v_{d}=0(8)
$$


For outlet conditions:

At $\mathrm{x}= \pm \infty, \mathrm{T}=\mathrm{constant}=300 \mathrm{~K}, \mathrm{P}=\mathrm{P}$, atmosphere, $(9)$

2. Symmetrical axis at chimney centre axis, i.e:

$$
\begin{aligned}
& u_{(x=+x)}=u_{(x=-x)}, v_{(x=+x)}=v_{(x=-x),} p_{(x=+x)}=p_{(x=-x)} \\
& \mu_{m}\left(\frac{\partial u_{d}}{\partial y}+\frac{\partial v_{d}}{\partial x}\right)_{(x=+x)}=\mu_{m}\left(\frac{\partial u_{d}}{\partial y}+\frac{\partial v_{d}}{\partial x}\right)_{(x=-x)}
\end{aligned}
$$

The gaseous fuel was natural gas with high ratio of methane which burns according to the following chemical reaction (complete combustion):

$$
\mathrm{CH} 4+2 \mathrm{O} 2 \longrightarrow \mathrm{CO} 2+2 \mathrm{H} 2 \mathrm{O}
$$

The molecular weight of carbon $(\mathrm{C})$, hydrogen $(\mathrm{H})$ and oxygen $(\mathrm{O})$ are 12, 2 and 32 respectively. Therefore, the combustion of one mole of methane with two moles of oxygen produce one mole of carbon dioxide with two moles of water, that means one $\mathrm{kg}$ of methane with four $\mathrm{kg}$ of oxygen to produce the following:

$$
\begin{gathered}
M_{\mathrm{CO}_{2}}=m_{\mathrm{CH}_{4}} \times \frac{W_{\mathrm{CO}_{2}}}{W_{\mathrm{CH}_{4}}} \\
M_{\mathrm{H}_{2} \mathrm{O}}=m_{\mathrm{CH}_{4}} \times \frac{W_{\mathrm{H}_{2} \mathrm{O}}}{W_{\mathrm{CH}_{4}}}
\end{gathered}
$$


Therefore, the fuel burning inside the chimney chamber follow the equation:

Heat released by burning fuel $=$ Heat absorbed by air + Heat radiated to all inside faces of the chamber.

$$
Q=m_{a} c_{p}\left(T_{f}-T_{a}\right)+\dot{\varepsilon} \sigma A_{p}\left(T_{f}^{4}-T_{w}^{4}\right)
$$

Where $\mathrm{Q}(\mathrm{kW})=$ mass, $\times$, calorific value of fuel

\section{2-4 Numerical Analysis:}

The turbulent flow of mixture (air and fuel) before and after the combustion process inside the system would be analyzed by standard k- $\varepsilon$ model. The SIMPLE algorithm with QUICK Scheme method used to solve the pressure -velocity coupling, momentum and energy equations respectively. These methods were explained by many references such as Ref.[16]. So, the Gambit and Fluent Codes are used to describe the results of this paper. Fig. 3 the study case of chimney system as designed by GAMBIT. 


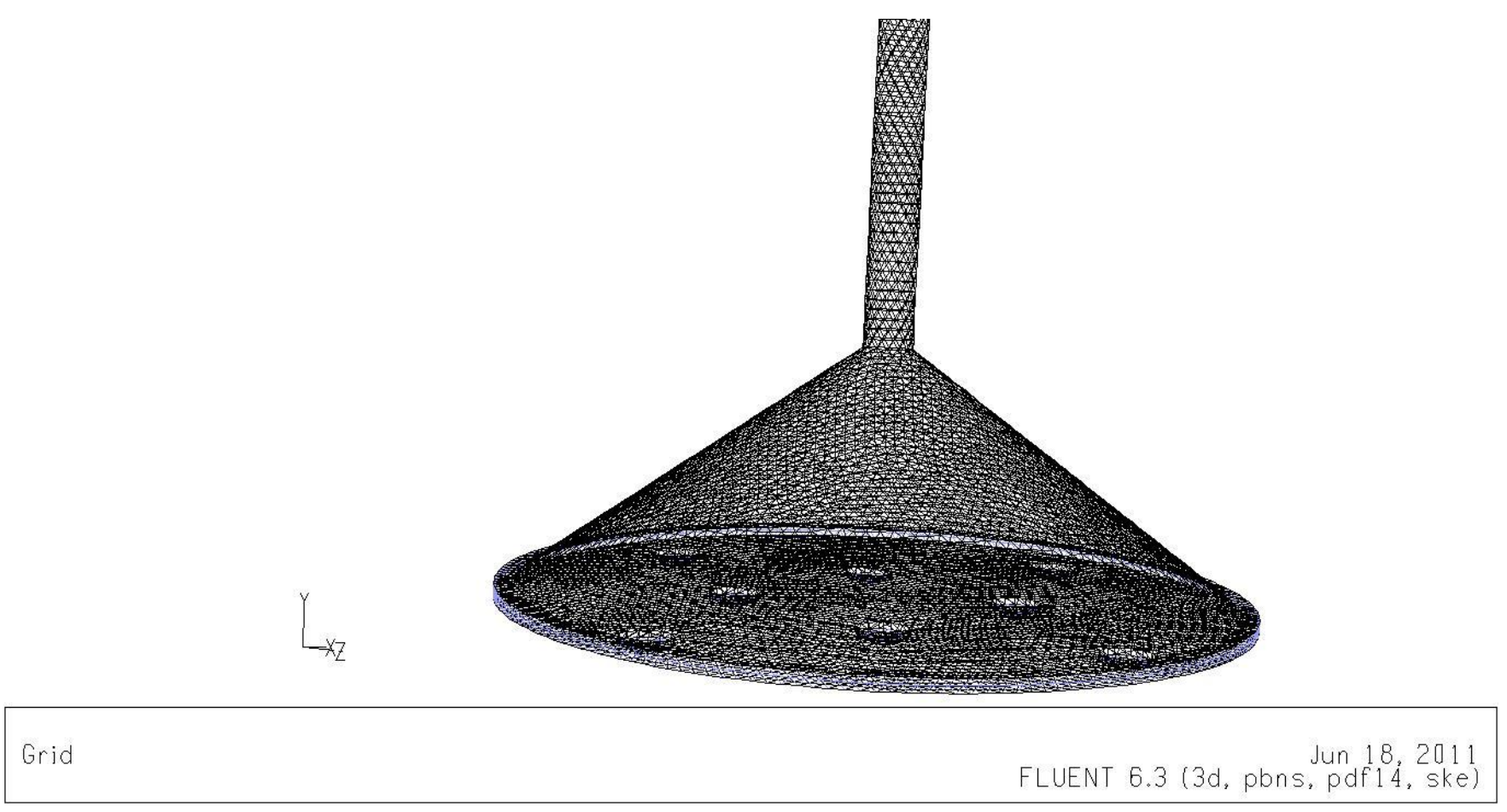

Fig.( 3) The Domain Grid As Designed By GAMBIT Code On Jun. 18, 2011

\section{3- Results And Discussion}

The heat energy transferred

from the flame inside the combustion chamber to circumferential wall which may be built as heat exchanger with another fluid (air or distillated water) will be transferred to be fluid which is in turn will absorb heat from the wall by convective heat transfer to rotate gas turbine or steam turbine. So, it might be use turbine at chimney depend the flue gases motion outside the system.

In this paper, three cases of gaseous fuel velocity input depending on the chamber capacity. These cases are

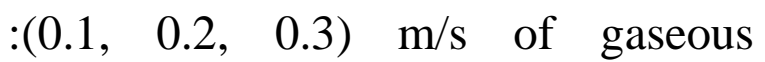
velocity input through anyone of the eight velocity input vents at the base. The central section plane which cut the system into two parts and cut two burners only is taken at this paper. 
There are some information about the combustion process where methane density (CH4 fuel) is $0.6679 \mathrm{~kg} / \mathrm{m}^{3}$. Therefore.

\begin{tabular}{|l|c|c|c|}
\hline Fuel velocity (m/s) & $\mathbf{0 . 1}$ & $\mathbf{0 . 2}$ & $\mathbf{0 . 3}$ \\
\hline Mass flow rate (for one burner) (kg/s) & 0.0524 & 0.105 & 0.157 \\
\hline $\begin{array}{l}\text { Mass flow rate (for eight burners of furnace) } \\
\text { (kg/s) }\end{array}$ & 0.419 & 0.839 & 1.259 \\
\hline
\end{tabular}

There are many reasons for the selection of turbine erection position inside the chimney requires further discussion. The first factor is the difference in static pressure gradient as shown in (Fig. 4 and 5).

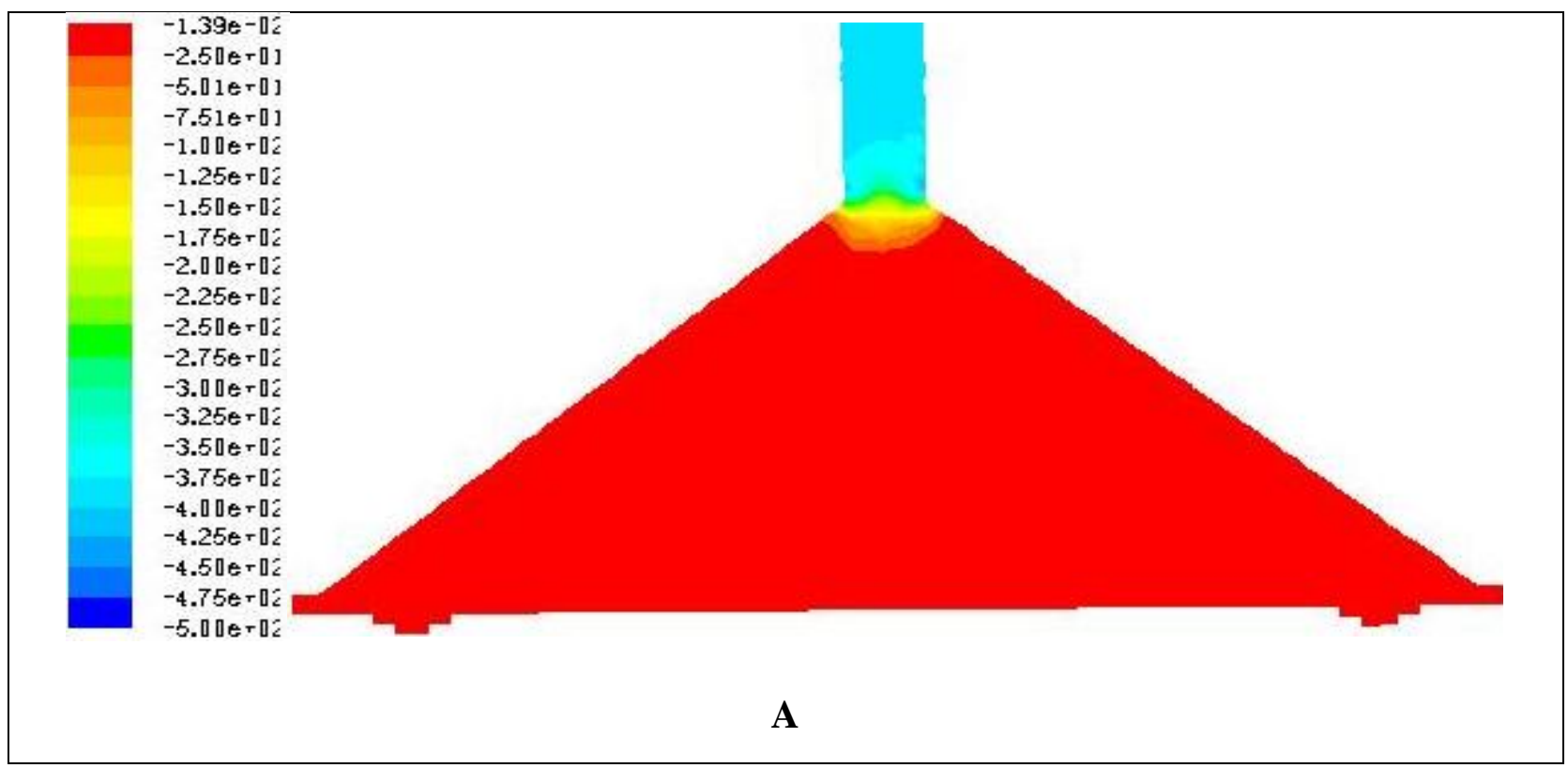




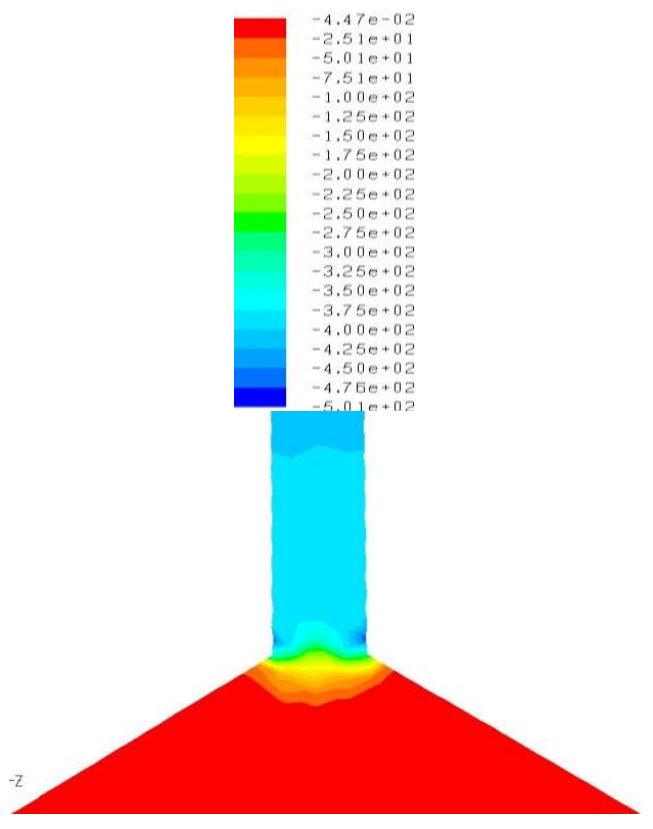

B

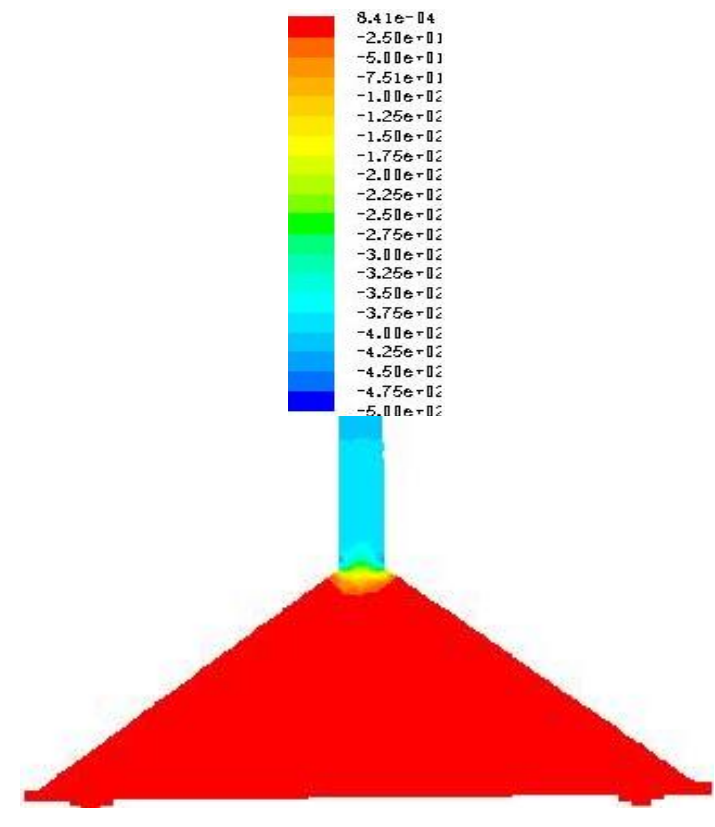

C

Fig. (4) Pressure gradient at A. $0.2 \mathrm{~m} / \mathrm{s}$, B. $0.1 \mathrm{~m} / \mathrm{s}$, C. $0.3 \mathrm{~m} / \mathrm{s}$ velocity of gaseous fuel input

The figure 4 arranged by Cartesian coordinates $\mathrm{X}-\mathrm{Y}-\mathrm{Z}$ as shown. High differences in static pressure values $\left(-5 \times 10^{+2}\right.$ to $\left.-1.39 \times 10^{-2}\right)$ are measured between the upper point of chimney as low pressure value to high value at the base outer circumference of collector. This high difference is created because of high height of chimney and the heat absorbed by air which accelerates the air velocity cause high relative pressure. It is observed that there are high difference between the gradient of chimney and combustion chamber. Therefore, this is one of reasons for turbine installation at this base. Furthermore, from the other shapes of Fig.4 (B, C), it is seen that the relative static pressure changed significantly with increasing the fuel velocity at input (from $0.1 \mathrm{~m} / \mathrm{s}$ to 
$0.3 \mathrm{~m} / \mathrm{s}$ ) . That is because of increasing the air density inside the collector in comparison with environment of station at the same altitude. This heat transferred with natural convection to increase the pressure gradient which reach the levels between $\left(-4.47 \times 10^{-2} \mathrm{~Pa}\right)$ and $\left(8.41 \times 10^{-4} \mathrm{~Pa}\right)$ for velocity of fuel $0.1 \mathrm{~m} / \mathrm{s}$ and $0.3 \mathrm{~m} / \mathrm{s}$ respectively. While the lower value is the same for all cases since they have the same height level of chimney.

Fig. 5 shows the static pressure distributions which is calculated from the central section of whole domain as circumferential mean values which support the validity of this study and prove the mentioned pressure values. It is observed that the three curves of pressure have the same value approximately or the difference is not sensible because of narrow domain of fuel velocity. The pressure gradient is approached to atmosphere at the inlet vent of the system (maximum value is zero) but it is increased while reach the top of chimney since high difference in relative pressure due to the heat and height of chimney which work as vacuum pressure to increase the air velocity. The validity of this work in comparison with domain of [15] shown in fig.6 which has higher difference than this paper because of high pressure difference as a result to high height of chimney (100m) and the solar flux of (200 to $\left.800 \mathrm{~W} / \mathrm{m}^{2}\right)$. 


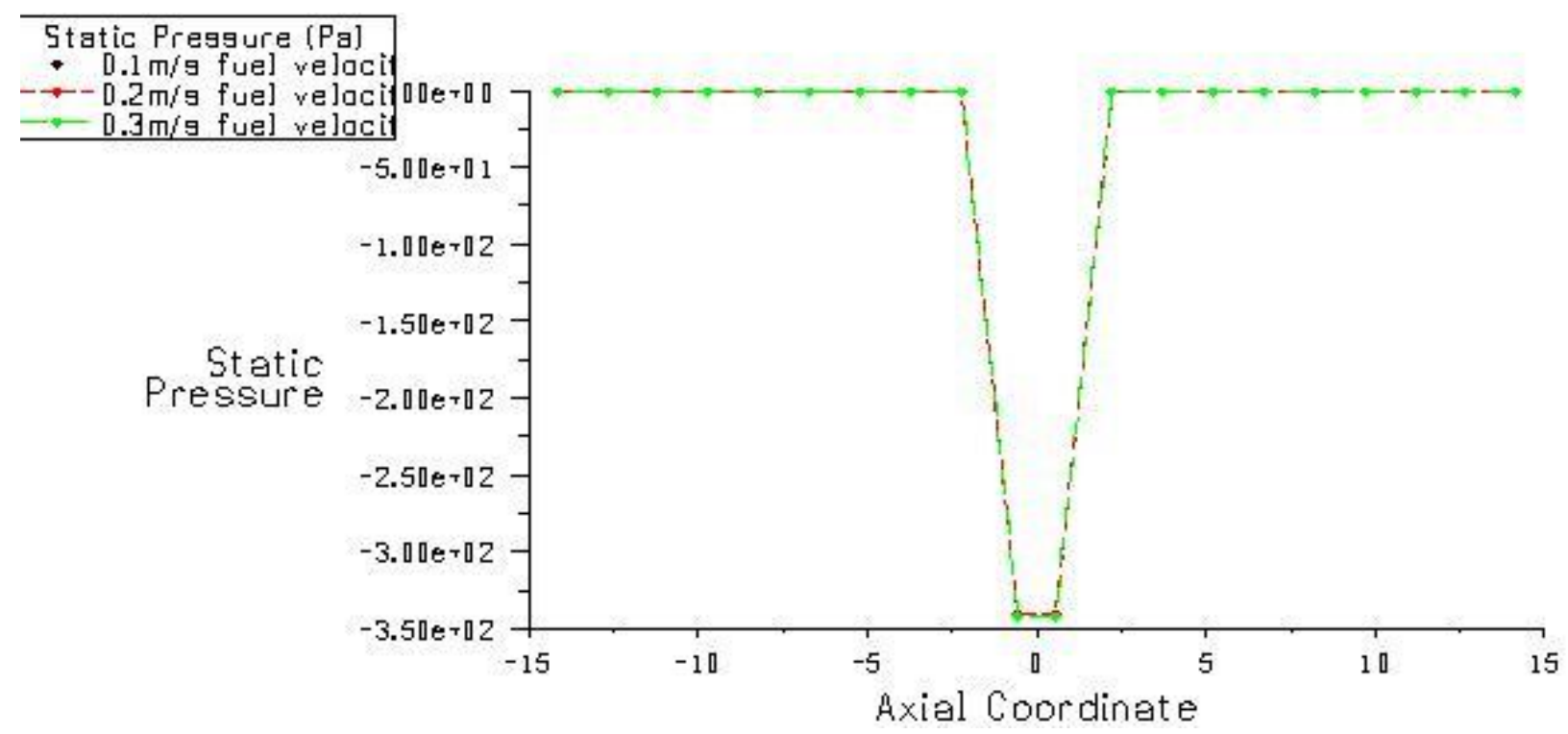

Fig. (5) Static Pressure Of Domain Calculated For Central Section Plane

Fig. 7 shows the temperature distribution inside the system. Fig.7A is an indication of heat absorbed or transferred to different trends of parts chose at $0.2 \mathrm{~m} / \mathrm{s}$ of fuel input velocity. This shape of temperature range $(1970 \mathrm{~K}$ to $300 \mathrm{~K})$ which is at ambient temperature of $300 \mathrm{~K}$.

FLUENT Code demonstrates wide ranges of measurements near the effective domain. The dominated temperature of air inside the chimney is $1100 \mathrm{~K}$ as observed by limited $1^{\text {st }}$ Iraq Oil \& Gas Conference ( $1^{\text {st }}$ IOGC) range contour which shown in Fig. 7A and 7B for velocity of fuel inside the system will be $0.2 \mathrm{~m} / \mathrm{s}$ but the maximum temperature value is at the bottom side distance of chimney and inside upper ceiling of the chamber. It is notably high hot place than other systemspace because the combustion of fuel and air happen under this place. This air speed increases in the direction of chimney centre.

The other shapes of Fig.7C and 7D denote to temperature difference at 
fuel velocity of 0.1 to $0.3 \mathrm{~m} / \mathrm{s}$ respectively. It is normally, there are gradually higher temperature ranges than $0.2 \mathrm{~m} / \mathrm{sof}$ fuel velocity. In $0.1 \mathrm{~m} / \mathrm{s}$ fuel velocity, it is normally lower than $0.2 \mathrm{~m} / \mathrm{s}$ because of lower mass flow rate. But in $0.3 \mathrm{~m} / \mathrm{s}$ observe lower value too since the combustion process takes place near the chimney base which gone outside the system as shown in fig.7D with yellow colour. This heat forces the velocity magnitude in the direction of chimney centre as a result to natural convection of air and forced convection of fuel input.
Therefore, fig. 8 shows the circumferential average of static temperature for three cases of paper study. It is found the higher value of temperature at the chimney is for 0.3 $\mathrm{m} / \mathrm{s}$ velocity of fuel as describe but the lower is for $0.1 \mathrm{~m} / \mathrm{s}$ and $0.2 \mathrm{~m} / \mathrm{s}$ lies between them. At the sides of chamber, the value of $0.1 \mathrm{~m} / \mathrm{s}$ is the higher as a result to complete combustion inside this furnace chamber, then the value of 0.2 and $0.3 \mathrm{~m} / \mathrm{s}$ respectively for the same reason.

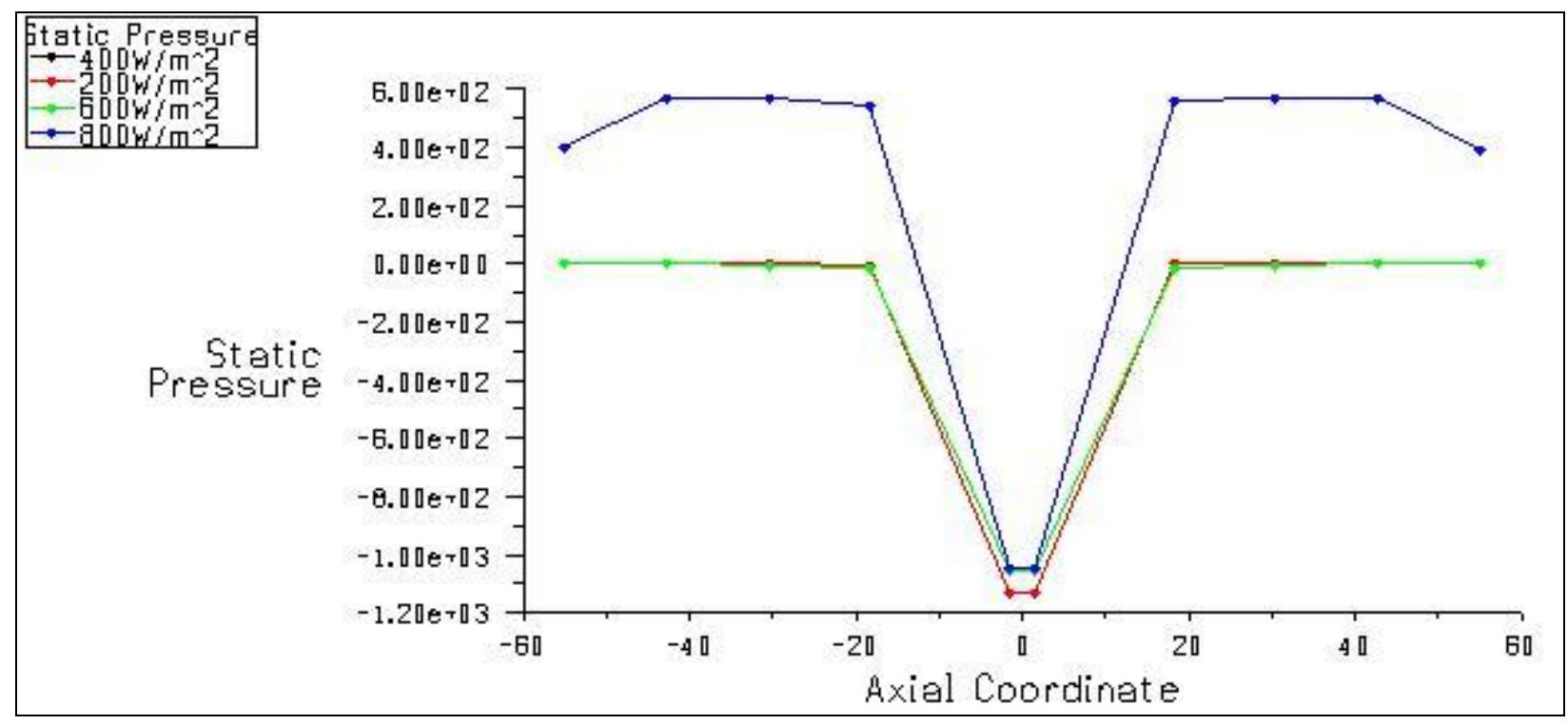

Fig. (6) Static Pressure Of Domain For [15] 

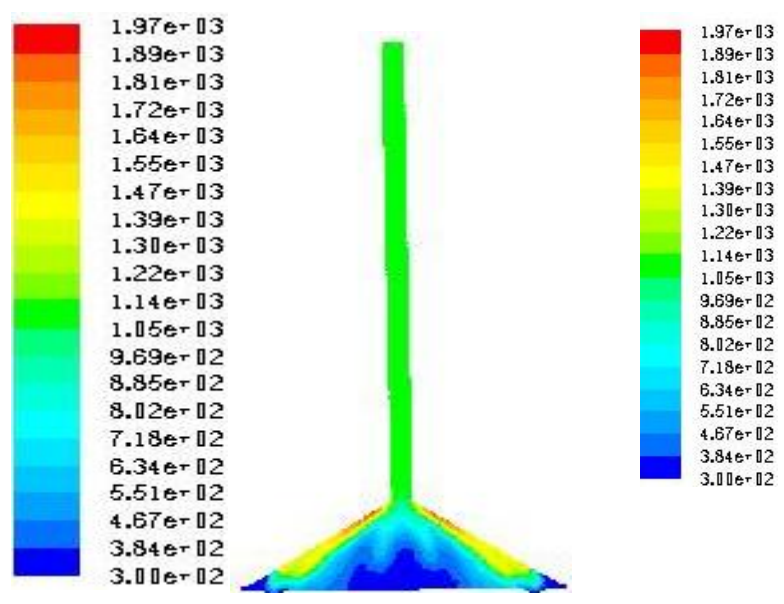

A

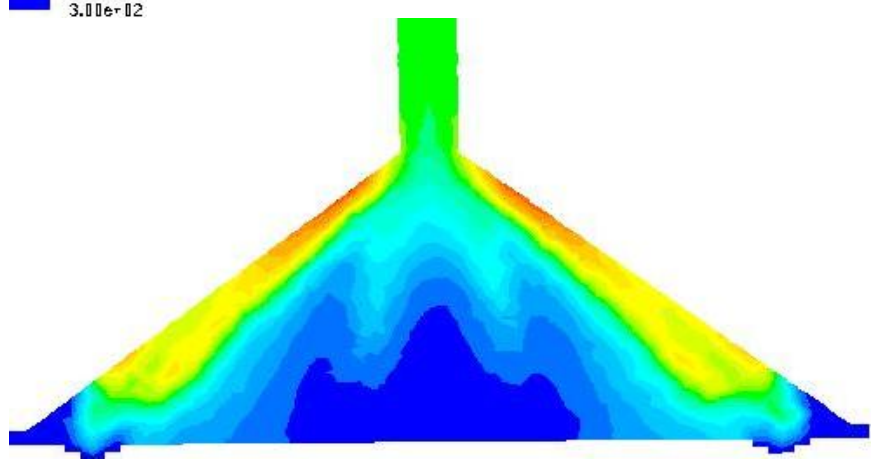

B

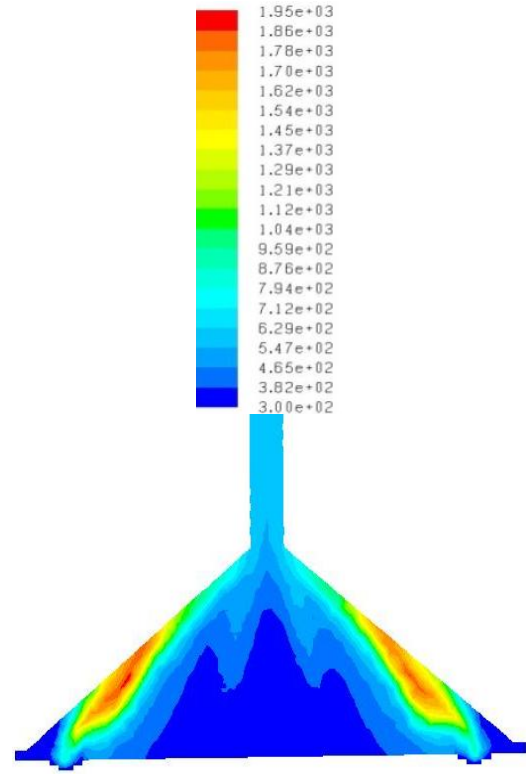

C

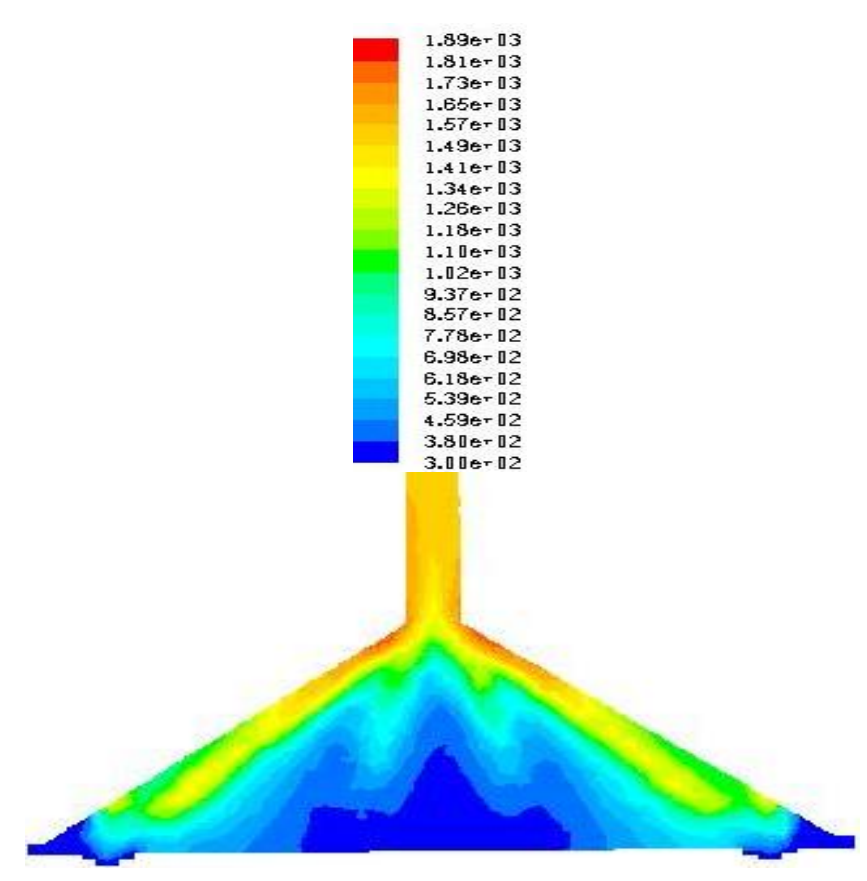

D

Fig. (7) Static Temperature At A And B $(0.2 \mathrm{~m} / \mathrm{S}), \mathrm{C}(0.1 \mathrm{~m} / \mathrm{S})$ And D $0.3 \mathrm{~m} / \mathrm{S})$ Of Fuel Input Velocity 
The velocity vectors of the system are shown in Fig.9 which indicates that high velocity magnitude at input fuel velocity of $0.1,0.2$ and $0.3 \mathrm{~m} / \mathrm{s}$ reaches 34.4, 46.6 and $58.2 \mathrm{~m} / \mathrm{s}$ respectively at the position of turbine at the lower part of chimney as shown in A and B of fig. 9 for $0.2 \mathrm{~m} / \mathrm{s}, \mathrm{C}$ for $0.1 \mathrm{~m} / \mathrm{s}$ and $\mathrm{D}$ for $0.3 \mathrm{~m} / \mathrm{s}$ velocity of fuel input. So, there is a low velocity gradient at the outer end of the base part of system. The velocity notably increases when directed to the chimney centre due to the heat accumulation increase, narrow area of chimney cover and low pressure gradient. The velocity range increases directly with increasing the heat flux of combustion as noted in Fig.9. These ranges are suitable for using big turbines at lower position of chimney or using multi-stage turbine to have high gain energy.

The circumferential average of velocity magnitude distribution on the system domain with its position in the central section for whole system with axial coordinates is presented by Fig.10. It is denoted that high velocity values lie at the chimney but low values at the end edges of chamber since the reasons mentioned in this paper before.The upper green curve of Fig. 10 denotes the velocity magnitudes in the axial coordinate calculated as average values of the central section of domain for velocity of fuel input $0.3 \mathrm{~m} / \mathrm{s}$ which interpritates high velocity of flue gases of combustion with increase the energy of fuel. It is observed that higher velocity values trend from the outer edge to the central part of domain (chimney) as mentioned before. The validity of these values shown by fig. 11 for Hannun,et. al.[15] which predict the same trend of curves for different values of power. 


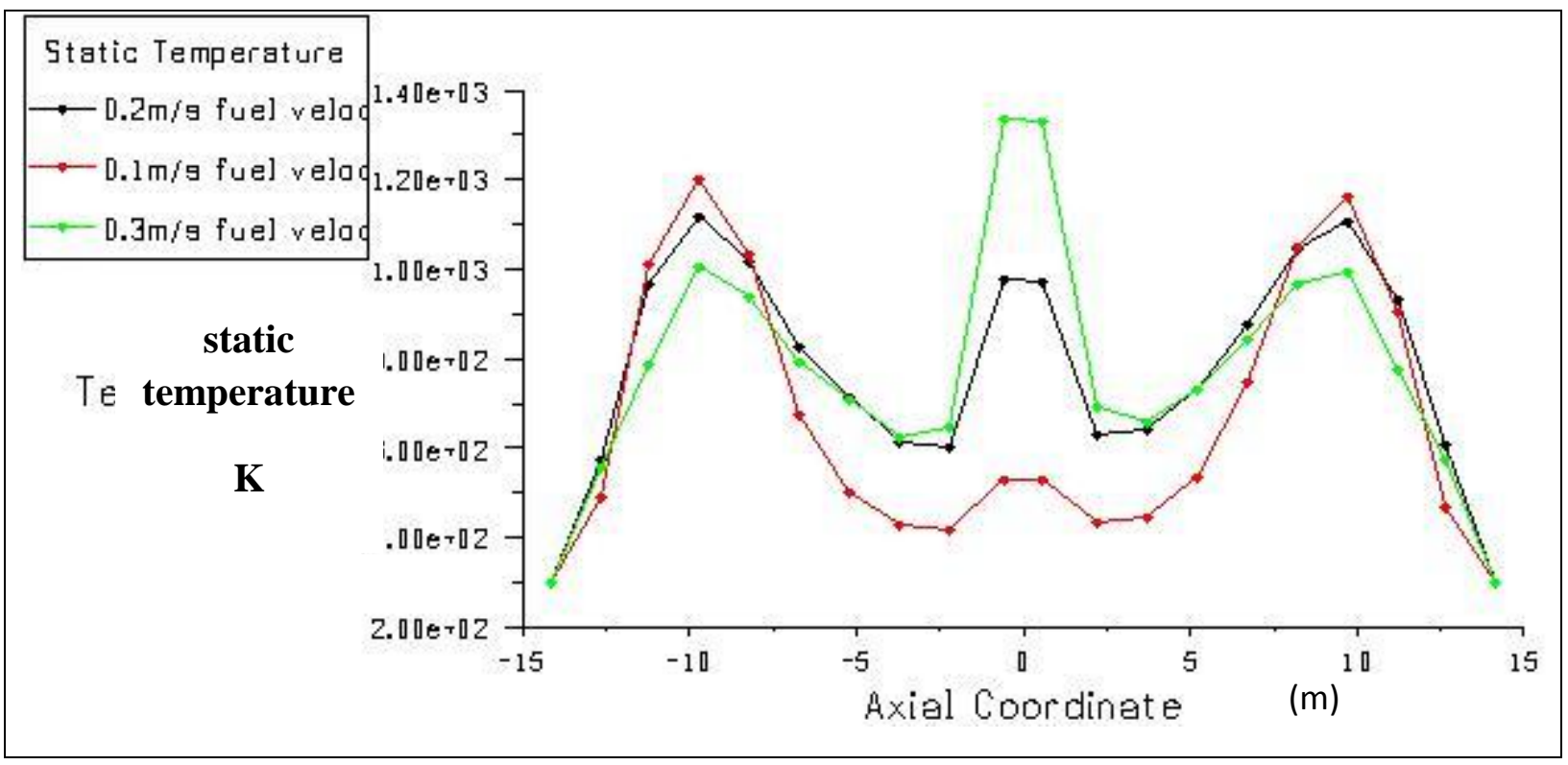

Fig.(8) Circumferential Average Of Static Temperature For Three Cases

So, the validity of this work that the programme code work properly to get logic results. Fig. 12 shows the concentration of species in combustion calculated as mass fraction. The first one is the gaseous fuel (methane $\mathrm{CH} 4$ ) which reasonable prediction for incoming fuel from burners to combustion chamber before the combustion process has high mass fraction at this place then gradually disappeared inside the furnace as a result to combustion. The second is carbon dioxide concentration where it has maximum value at the end of combustion after the reaction complete with the same manner of water particles concentration shown in figure. It is vice versa to concentration of oxygen because it inter the reaction before burning of fuel. The forth slip is for nitrogen, its concentration is very high in large space of domain except in the combustion space because it is not interring the combustion process but it has high portion of air constituents. The sixth shape in fig. 
for the density $\left(\mathrm{kg} / \mathrm{m}^{3}\right)$, high density

but the lower at the combustion space.

is at the input edges of air and burners

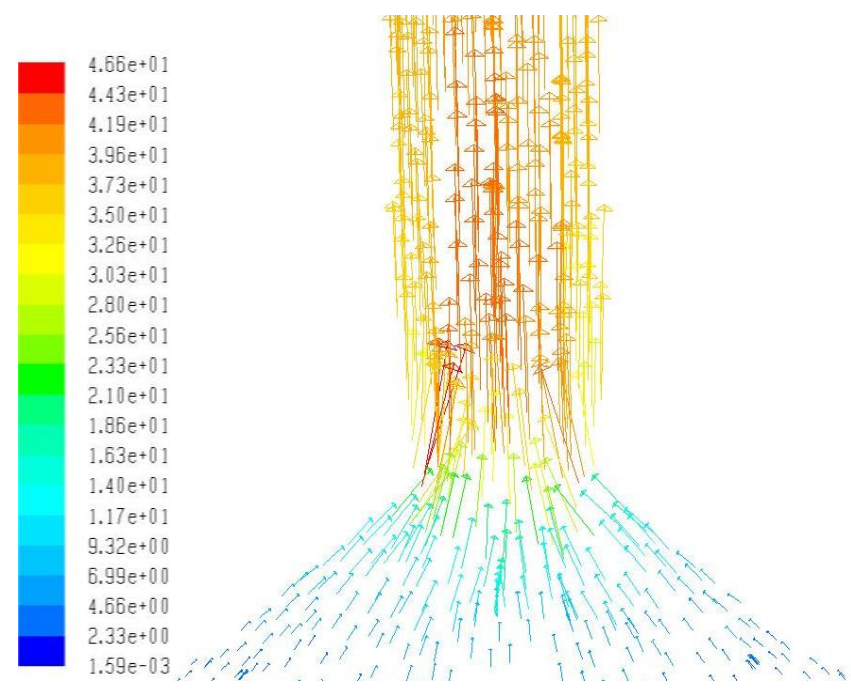

A

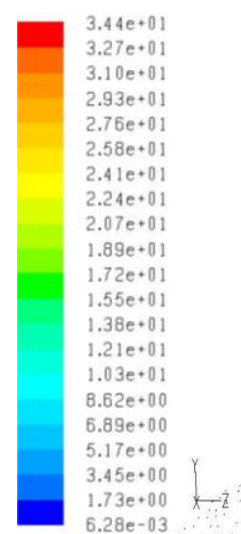

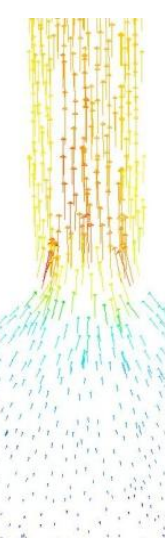

$\mathrm{C}$

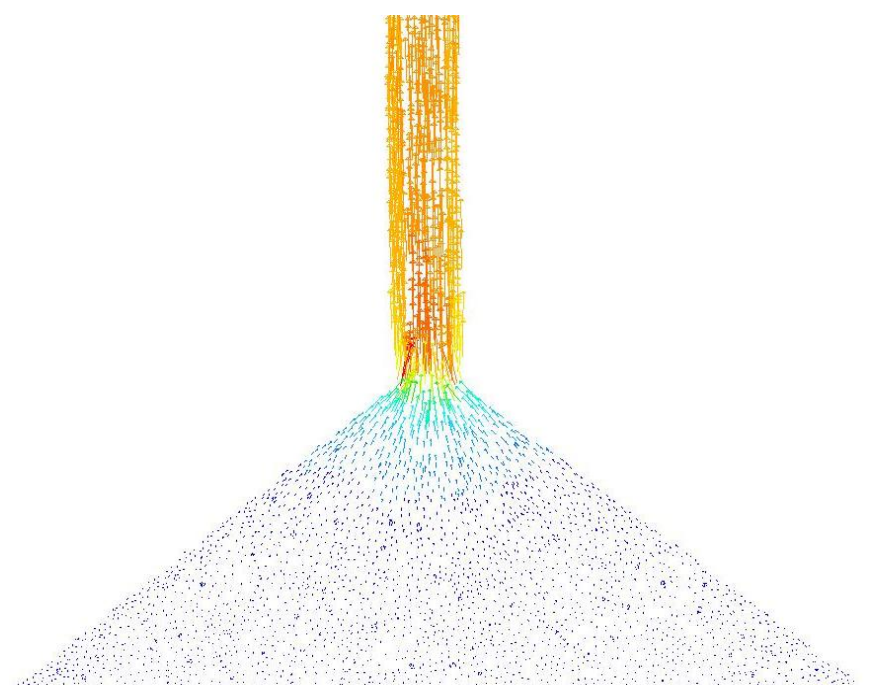

B

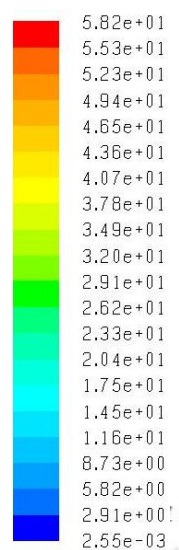

$2.55 \mathrm{e}-03$

$\mathrm{D}$

Fig. (9) Velocity Vector Distribution(M/S) At A And B (0.2m/S), C (0.1m/S) And D (0.3m/S) Of Fuel Input velocity 


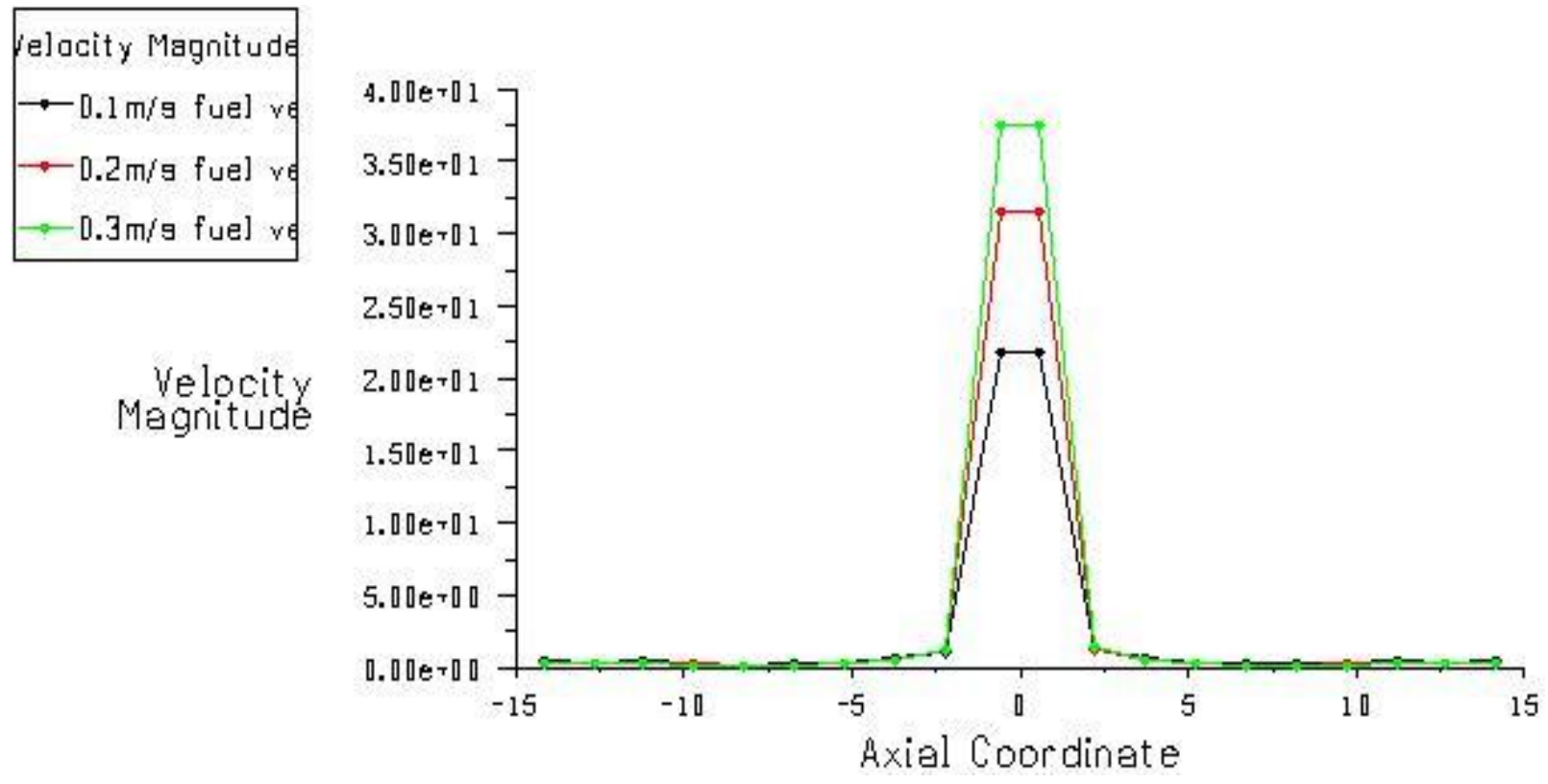

Fig. (10) Circumferential average of velocity magnitude for different velocity input of fuel

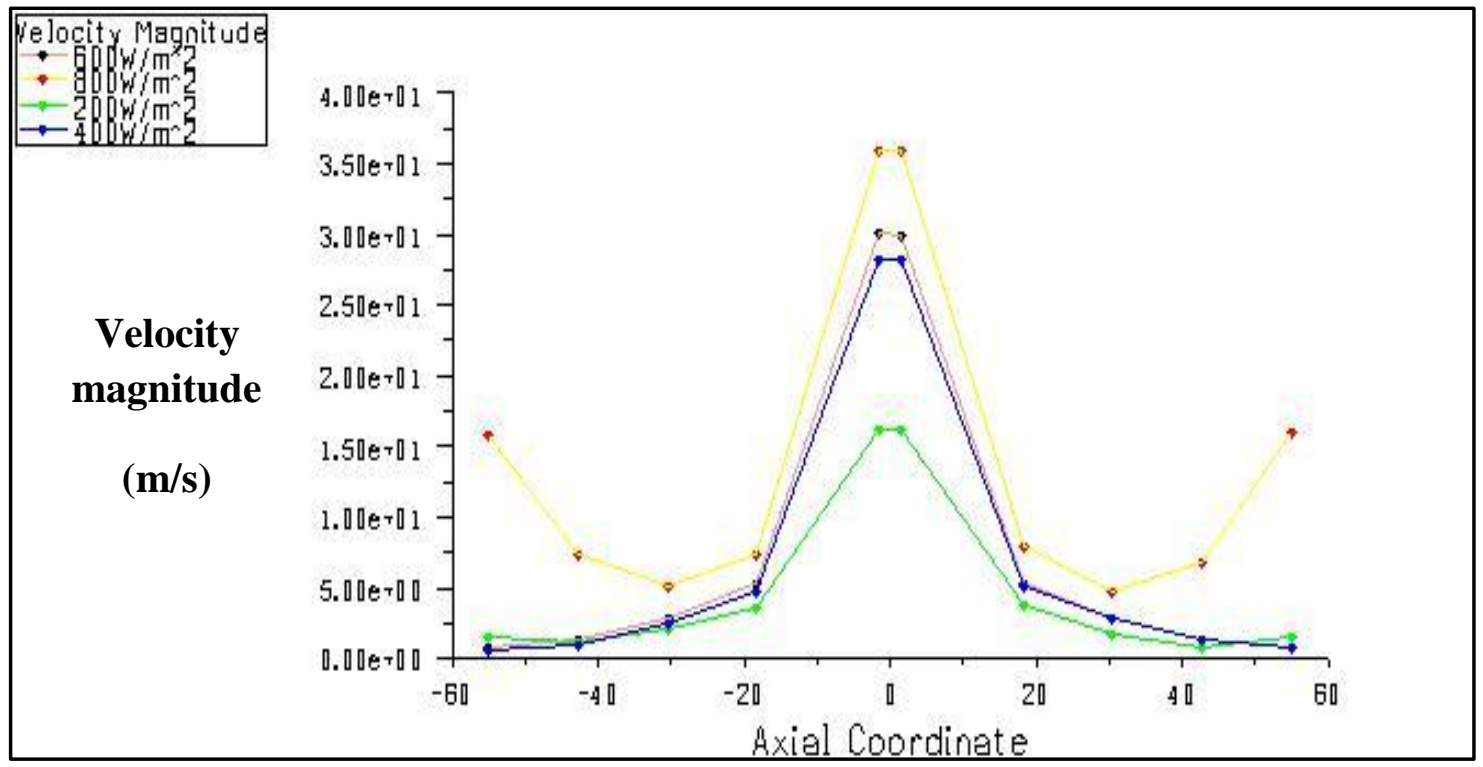

Fig. (11)Circumferential average of velocity magnitude for different power presented by [15] 


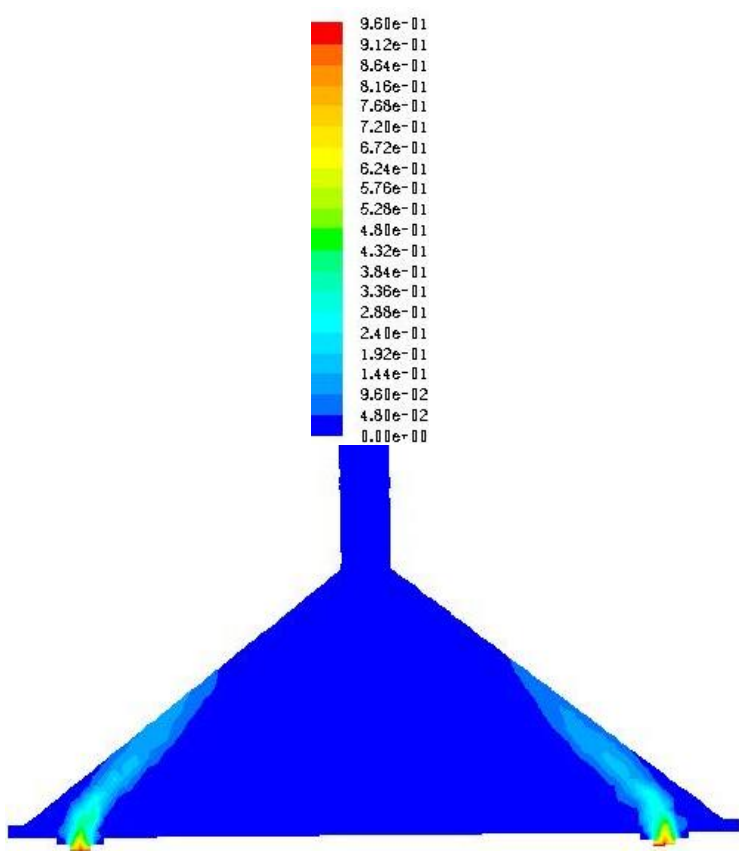

$\mathrm{CH}_{4}$

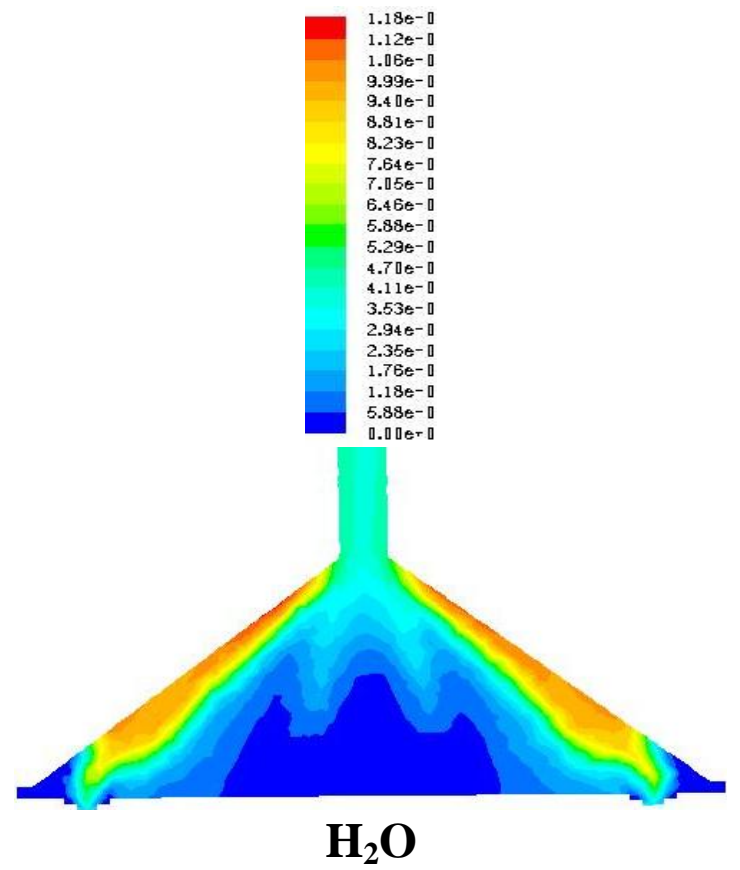

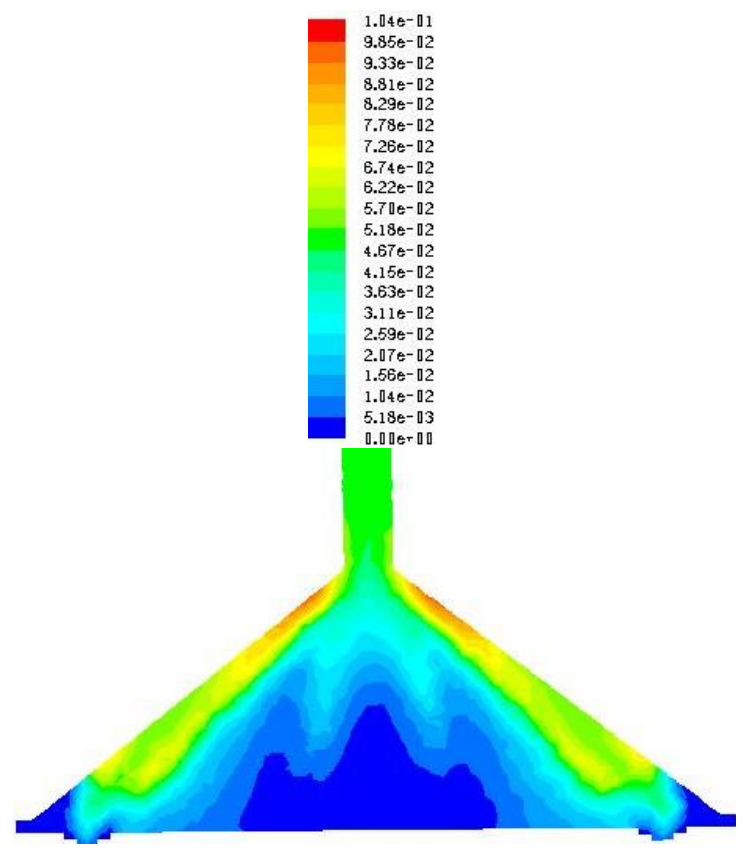

$\mathrm{CO}_{2}$

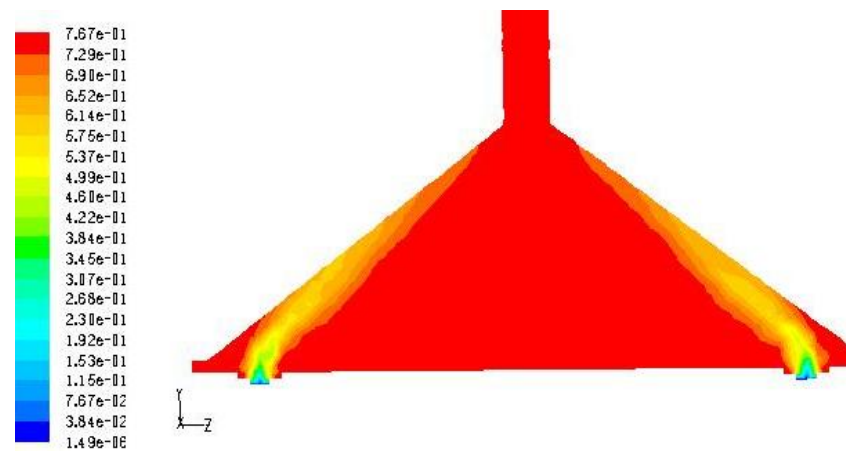

$\mathbf{N}_{2}$ 


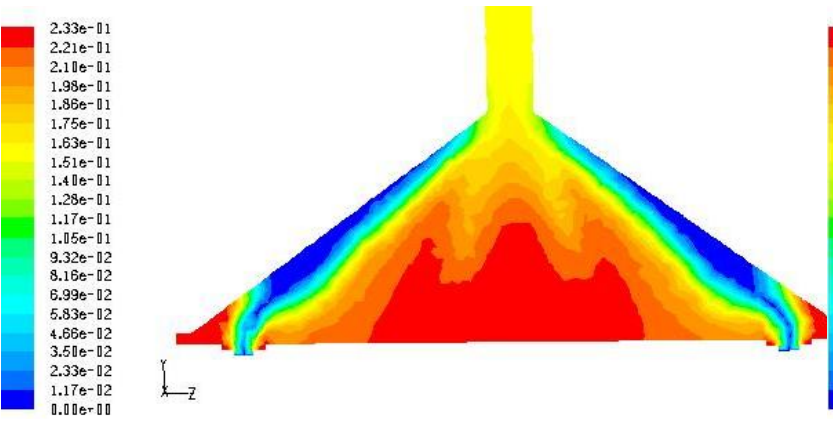

$\mathbf{O}_{2}$

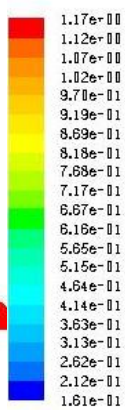

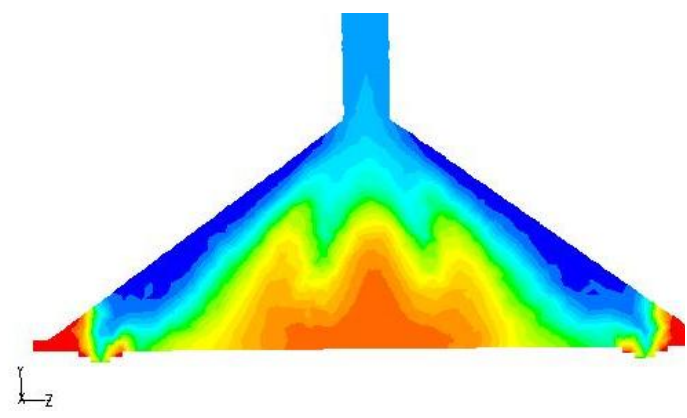

Density $\left(\mathrm{kg} / \mathrm{m}^{3}\right)$

Fig.(12) The concentration of species (mass fraction) and density in $0.2 \mathrm{~m} / \mathrm{s}$ velocity of fuel

\section{Conclusions:}

\section{It is noted from the}

numerical solution and the analysis of chimney tower system for the predicted case study, there are some conclusions presented about the circumferential parameters such as:

1- It is reasonable to build CHIMNEY TOWER at the oil spilling units or refinery units to use the compound gases outgoing the petroleum wells.

2- The present design could be depended to erect in oil stations mentioned in 1 above or may be arranged to be favorable for anyone.
3- The design of burners and their situations could be enhanced (by using swirlers) to get complete combustion process with high efficiency.

4- The velocity of mixture is high at the base section of chimney but it is very low at the outer edge of canopy and then converged in developing to the chimney centre.

5- The temperature is the highest at chamber canopy when the combustion process be complete but at increase the flow rate of fuel (as in case $0.3 \mathrm{~m} / \mathrm{s}$ ) high heat energy 
transferred to chimney which

may be considered as losses or

changing the design of

combustion chamber or using

heat exchanger for the bottom

chimney part.

6- The pressure gradient is approached to atmosphere at the inlet vent of the system but it is increased while reach the top of chimney since high difference in relative pressure due to the heat. Also, the height of chimney which work as vacuum pressure to increase the air velocity.

7- Due to the high velocity recorded at the expansion of chimney, the power turbineis preferred to build in.

8- The boiler of power plant may be erected around the combustion chamber to use the heat transferred directly for both gaseous and/or steam power plants. 


\section{$\underline{\text { References }}$}

1. Hannun R.M.," (2005) Modeling of Solar Thermal Power Plant" , M.Sc. thesis, University of Technology, Mechanical Engineering Department, Baghdad,.

2. Lefebure A.H. (1999) "Gas Turbine Combustion", Second Edition, Taylor and Francis Group, UK (London).

3. Backström T. and Fluri T. (2006) " Maximum fluid power condition in solar chimney power plants -An analytical approach", Solar Energy 80, pp. 1417-1423.

4. Haaf, W., Friedrich, K., Mayr, G., Schlaich, J. (1983), "Solar chimneys, part I: principle and construction of the Manzanares", pilot plant in International Journal of Solar Energy 2, 3-20,

5. Haaf, W. (1984) "Solar chimneys, part II: preliminary test results from the Manzanares pilot plant”, International Journal of Solar Energy 2, 141-161,.

6. Schlaich, J. (1994) "The Solar Chimney: Electricity from the Sun", Deutsche Verlags-Anstalt, Stuttgart.

7. Pretorius J. P. and Kröger D.G. (2006)

"Critical evaluation of solar chimney power plant performance ", Solar Energy 80, pp. $535-544$.

8. Ninic N. , Nizetic S. (2009) "Elementary theory of stationary vortex columns for solar chimney power plants", Science direct, Solar Energy 83, pp476-476.

9. Sislian J.P. (1988) Jiang L.Y. and Cusworth R.A., "Laser Doppler Velocimetry Investigation of the Turbulence Structure of Axisymmetric Diffusion Flames" Progress in Energy and Combustion Science, Vol.14, No.2, PP.99-146. 
10. Love N.D. (2009) Parthasarathy R.N. and Gollahalli S.R., "Rapid Characterization of Radiation and Pollutant Emissions of Biodiesel and Hydrocarbon Liquid Fuels", ASME, Journal of Energy Resources Technology.

11. Azazi F.A. (2001) "Aerodynamics and Thermal Prediction of AlHartha Power Generation Plant Furnace", Ph.D. Thesis, College of Engineering, Basrah University, Iraq.

12. Alhabbubi M.M. (2002) "Radiative Heat Transfer in Boilers Using the Zonal Method", MSc. Thesis, Mechanical Engineering, Babylon University,

13. Sobolev V. (2008), Snegirev A., Shinder Y. and Lupulyak S., "Modeling of Turbulent Diffusion Combustion in the Jet Flames of the Rectilinear-Swirl Burners", The 3rdinternational conference "Heat and mass transfer and Hydrodynamics in swirling flows", 21-23 October, Moscow, Russia.

14. Hannun R.M.(2009) “Three Dimensional Aerodynamic and Temperature Predictions for Nassiriya Power Plant Boiler Furnace", Ph.D. Thesis, College of Engineering, Basrah University, Iraq.

15. Hannun R.M., Ugla A.A. and Abid G.A.(2011), "Prediction of Power Chimney Parameters Influenced the Operation at Nassiriya City", Thi-Qar University Journal for Engineering Sciences, 2(2), 84-105.

16. Tao WQ. (2001), 'Numerical heat transfer”, 2nd ed. Xi'an, China: Xi'an Jiaotong University Press. 


\section{NOMENCLATURE}

\section{Symbol Definition}

a Thermal diffusivity $\left(\mathrm{m}^{2} / \mathrm{s}\right)$.

$\mathbf{A}_{\mathrm{p}}$ Area of the inside face of combustion chamber $\left(\mathrm{m}^{2}\right)$.

g Gravitational body force $\left(\mathrm{m} / \mathrm{s}^{2}\right)$

k Kinetic energy $\left(\mathrm{m}^{2} / \mathrm{s}^{2}\right)$

L Combustion chamber canopy height ( $\mathrm{m})$.

$\mathbf{m}_{\mathrm{a}}$ air mass flowrate $(\mathrm{kg} / \mathrm{s})$

M Molecular weight $(\mathrm{kg} / \mathrm{kmol})$

$\mathrm{C}_{\mathrm{p}} \quad$ Specific heat at constant pressure

p The local absolute pressure $\mathrm{Pa}$

$\mathbf{R}_{\mathrm{a}} \quad$ Rayleigh number

$\mathbf{T}_{\mathrm{a}} \quad$ air temperature $(\mathrm{K})$

$\mathbf{T}_{\mathrm{f}} \quad$ Fuel temperature (K).

$\mathbf{T}_{\mathrm{w}} \quad$ Wall temperature (K).

$\mathbf{u}, \mathbf{v}$ Average velocity at $\mathrm{x}, \mathrm{y}$ directions respectively

W Weight (kg) 
É Emissivity factor

\& Dissipation rate $\left(\mathrm{m}^{2} / \mathrm{s}^{3}\right)$

$\boldsymbol{\beta}$ Coefficient of Thermal expansion (1/K)

$\lambda$ The heat conduction coefficient ( W/mK)

$\boldsymbol{\mu} \quad$ Dynamic viscosity $(\mathrm{kg} / \mathrm{m} . \mathrm{s})$

v Kinematic viscosity $\left(\mathrm{m}^{2} / \mathrm{s}\right)$

p Density $\left(\mathrm{kg} / \mathrm{m}^{3}\right)$ 